\title{
Hantavirus infection: a global zoonotic challenge
}

\author{
Hong Jiang ${ }^{1 \#}$, Xuyang Zheng ${ }^{1 \#}$, Limei Wang ${ }^{2}$, Hong Du ${ }^{1}$, Pingzhong Wang ${ }^{1 凶}$, Xuefan Bai $^{1 凶}$ \\ 1. Center for Infectious Diseases, Tangdu Hospital, Fourth Military Medical University, Xi'an 710032, China \\ 2. Department of Microbiology, School of Basic Medicine, Fourth Military Medical University, Xi'an 710032, \\ China
}

Hantaviruses are comprised of tri-segmented negative sense single-stranded RNA, and are members of the Bunyaviridae family. Hantaviruses are distributed worldwide and are important zoonotic pathogens that can have severe adverse effects in humans. They are naturally maintained in specific reservoir hosts without inducing symptomatic infection. In humans, however, hantaviruses often cause two acute febrile diseases, hemorrhagic fever with renal syndrome (HFRS) and hantavirus cardiopulmonary syndrome (HCPS). In this paper, we review the epidemiology and epizootiology of hantavirus infections worldwide.

\section{KEYWORDS hantavirus; Bunyaviridae, zoonosis; hemorrhagic fever with renal syndrome; hantavirus cardiopulmonary syndrome}

\section{INTRODUCTION}

Hantaviruses are members of the Bunyaviridae family that are distributed worldwide. Hantaviruses are maintained in the environment via persistent infection in their hosts. Humans can become infected with hantaviruses through the inhalation of aerosols contaminated with the virus concealed in the excreta, saliva, and urine of infected animals (Jiang et al., 2014). Over 50 species of hantaviruses have been identified worldwide (Zuo et al., 2011). The spectrum of illnesses caused by hantaviruses varies with the particular virus involved. For example, Andes virus (ANDV) is associated with severe hantavirus cardiopulmonary syndrome (HCPS), whereas Prospect Hill virus (PHV) is not associated with human disease (Spiropoulou et al., 2007). Pathogenic hantaviruses can cause two diseases in humans: hemorrhagic fever with renal

Received: 28 October 2016, Accepted: 5 January 2017,

Published online: 23 January 2017

\# These authors contributed equally to this work.

$\triangle$ Correspondence:

Pingzhong Wang, Phone: +86-29-84777853, Fax: +86-29-83515039,

Email: wangpz63@126.com

ORCID: 0000-0002-4468-4729

Xuefan Bai, Phone: +86-29-84777852, Fax: +86-29-83537377,

Email: xfbai2011@163.com

ORCID: 0000-0003-4609-4877 syndrome (HFRS) and HCPS (Wang et al., 2012). According to the latest data, it is estimated that more than 20,000 cases of hantavirus disease occur every year globally, with the majority occurring in Asia. Nevertheless, the number of cases in the Americas and Europe is steadily increasing. In addition to the pathogenic hantaviruses, several other members of the genus have not been associated with human illness.

Hantavirus virions are generally spherical in nature, with an average diameter of about 80 to $120 \mathrm{~nm}$ (Jonsson et al., 2010). The hantavirus genome consists of three segments, designated L (large), M (middle), and S (small). The L segment encodes an RNA-dependent RNA polymerase; the M segment encodes a glycoprotein precursor that is further processed to produce $\mathrm{Gn}$ and Gc transmembrane glycoproteins; and the S segment encodes a nucleocapsid protein (Hall et al., 2010). Despite the differences in distribution between Old World and New World hantaviruses in various geographic areas and the various diseases they induce, they exhibit a similar organization of nucleotide sequences and similar aspects in their life cycles (Jonsson et al., 2010). Hantaviruses mainly infect vascular endothelial cells in humans and induce vascular endothelial dysfunction in capillaries and small vessels. Therefore, the basic pathology of hantavirus-associated diseases is characterized by 
a dramatic increase in vascular permeability (Jiang et al., 2016). The immune response plays an important role in the pathogenesis of hantavirus infection ( $\mathrm{Yu}$ et al., 2012). However, the underlying pathophysiological mechanisms leading to increased vascular permeability are not fully understood. Thus far, the available forms of treatment for hantavirus infections have been limited.

\section{DISEASES CAUSED BY HANTAVIRUS AND THE RESERVOIRS}

\section{Hemorrhagic fever with renal syndrome (HFRS)}

Although China has recorded what were likely hantavirus infections in ancient literature, dating back to the $12^{\text {th }}$ century (Song, 1999), HFRS was first clinically recognized in 1931 in northeast China (Zhang WY et al., 2014). HFRS first came to the attention of western physicians when 3,200 United Nations troops fell ill in Korea between 1951 and 1954 (Schmaljohn and Hjelle, 1997). The first pathogenic hantavirus was isolated along the Hantaan River, in South Korea in 1976 by Lee et al., who named it the hantaan virus (HTNV) (1978). Hantaan, Seoul, Dobrava, and Puumala viruses are prevalent mainly in Europe and Asia, and are referred to as Old World hantaviruses. Five clinical phases are manifested in typical HFRS patients, including fever, hypotensive shock, and oliguric, polyuric, and convalescent phases. Furthermore, some of these phases overlap in severe cases, but might not be evident in mild cases of the disease (Wang et al., 2014). The incidence of HFRS in males is over three times greater than that in females. HFRS outbreaks can vary depending on the season, with most cases in epidemic areas occurring in the winter to early spring. Farmers account for the largest number of cases (Huang et al., 2012; Zhang S et al., 2014), especially in China. In recent years, new foci of infection have been detected and the endemic areas have extended beyond rural areas. Several factors are thought to be related to the expanding endemic trend of hantavirus infection, including rapid economic development, urbanization, human migration, and the effects of climate change (Zuo et al., 2011). Several inactivated vaccines have been generated from hantavirus in cell cultures or the rodent brain, and a few of these have been licensed for use in humans in Korea and China (Kruger et al., 2011). Inactivated monovalent vaccines reportedly have a protective efficacy of $93.77 \%-97.61 \%$ and inactivated bivalent vaccines, a protective efficacy of nearly $100 \%$ (Kruger et al., 2011). DNA vaccines and attenuated live vaccines are currently under evaluation in clinical trials. To our knowledge, no licensed vaccines currently exist in other countries, probably because of the relatively low incidence of HFRS. The use of antiviral agents is seldom re- ported, but ribavirin has been tested and its therapeutic efficacy has been proven in HFRS patients in China (Huggins et al., 1991).

\section{Nephropathia epidemica (NE)}

Nephropathia epidemica (NE) was first described in Sweden in the 1930s and thousands of hantavirus infection cases occur annually throughout Europe (Latus et al., 2015b). Although a number of various hantavirus species [e.g., Dobrava-Belgrade virus (DOBV) and Tula hantavirus (TULV)] are circulating in Europe, Puumala virus (PUUV) is by far the most prevalent pathogen (Manigold and Vial, 2014; Kruger et al., 2013). In central and northern Europe, PUUV is responsible for thousands of NE cases annually. NE is a mild form of HFRS that is characterized by acute kidney injury (AKI) and thrombocytopenia. The occurrence of thrombocytopenia in infected patients varies from 39\% to $98 \%$ (Krautkramer et al., 2013). Severe thrombocytopenia is very common, however, bleeding complications are uncommon in acute NE (Latus et al., 2015a). Smokers reportedly exhibit more severe kidney injury than non-smokers in cases of PUUV infection (Tervo et al., 2015).

\section{Hantavirus cardiopulmonary syndrome (HCPS)}

In 1993, a previously unrecognized syndrome (HCPS) was first described in the United States (Peters et al., 2002). Subsequently, Sin Nombre virus (SNV) was identified as the etiological agent (Ksiazek et al., 1995). SNV and ANDV are prevalent mainly in North and South America, and are referred to as New World hantaviruses. Approximately 43 strains have been reported in the Americas, and 20 of those strains are associated with human disease. In patients with HCPS, the primary target organ is the lungs (Table 1). Most cases occur during the late spring and early summer months, in contrast to hantavirus infections in Asia. The seroprevalence of hantavirus has been reported in healthy populations (Ferrer et al., 2003; Armien et al., 2004). In North America, SNV is the most prevalent hantavirus that causes HCPS (Knust and Rollin, 2013), whereas in South America, ANDV is the most significant pathogenic hantavirus, with ongoing discovery of new strains (Jonsson et al., 2010; Firth et al., 2012). Most of the South American hantavirus strains are divided into three monophyletic groups, referred to as the Andes, Laguna Negra, and Rio Mamore clades (Firth et al., 2012). ANDV is the only hantavirus with person-to-person transmission, a characteristic that places tremendous challenges to the healthcare systems of Argentina and Chile (Figueiredo et al., 2014; MartinezValdebenito et al., 2014). Recently, HCPS was reportedly induced by PUUV in Germany (Vollmar et al., 2016). Symptomatic and supportive treatment remain the most important treatment for the lack of specific therapeutics for HCPS. 
Table 1. General features of HFRS, NE and HCPS

\begin{tabular}{|c|c|c|c|}
\hline & HFRS & $\mathrm{NE}$ & HCPS \\
\hline Common features & \multicolumn{3}{|c|}{ sudden fever, prostration, myalgia and abdominal discomfort } \\
\hline Symptoms & \multicolumn{2}{|c|}{$\begin{array}{l}\text { hemorrhage, petechiae, inflammatory symptoms of the eye, acute } \\
\text { myopia, varying degrees of acute renal failure }\end{array}$} & $\begin{array}{l}\text { dry cough, rapidly increasing } \\
\text { dyspnea } \\
\text { On chest radiography, rapidly } \\
\text { evolving bilateral interstitial } \\
\text { edema }\end{array}$ \\
\hline Clinical phases & $\begin{array}{l}\text { five phases (febrile, hypotensive, } \\
\text { oliguric, polyuric, convalescent) }\end{array}$ & $\begin{array}{l}\text { five phases (febrile, hypotensive, } \\
\text { oliguric, polyuric, convalescent) }\end{array}$ & $\begin{array}{l}\text { three phases (prodromal, } \\
\text { cardiopulmonary, } \\
\text { convalescent) }\end{array}$ \\
\hline Main target organ & kidneys & kidneys & lungs \\
\hline Morbidity rate & $1 \%-12 \%$ & $0.1 \%-1.0 \%$ & $40 \%-50 \%$ \\
\hline Complications & $\begin{array}{l}\text { acute encephalomyelitis, bleeding, } \\
\text { multiorgan dysfunction, pituitary } \\
\text { hemorrhage, glomerulonephritis, } \\
\text { pulmonary edema, shock, acute } \\
\text { respiratory distress syndrome, } \\
\text { disseminated intravascular } \\
\text { coagulation, lethal outcome }\end{array}$ & $\begin{array}{l}\text { acute encephalomyelitis, bleeding, } \\
\text { multiorgan dysfunction, need of } \\
\text { dialysis, perimyocarditis, pituitary } \\
\text { hemorrhage, pulmonary edema, } \\
\text { shock, lethal outcome }\end{array}$ & $\begin{array}{l}\text { renal insufficiency, } \\
\text { thrombocytopenia, bleeding, } \\
\text { myalgia, headache, nausea, } \\
\text { vomiting, diarrhea, shock, } \\
\text { lethal outcome }\end{array}$ \\
\hline
\end{tabular}

Note: HFRS, hemorrhagic fever with renal syndrome; NE, nephropathia epidemica; HCPS, hantavirus cardiopulmonary syndrome. NE is a mild form of HFRS. (Maes et al., 2009; Papa, 2012; Mustonen et al., 2013; Jiang et al., 2016)

\section{Pathogenic hantaviruses and their reservoirs}

Rodents, shrews, moles, and bats are all reservoir hosts for hantaviruses. Although persistent infection can become established and high titers of neutralizing antibodies can accumulate, these reservoirs remain asymptomatic following infection (Vaheri et al., 2013; Yu et al., 2014). Each hantavirus is associated with a distinct rodent host species, and spillover to other rodent species seems to induce the production of specific antibodies and clearance of the virus (Spengler et al., 2013). Hantaviruses apparently co-evolve with their hosts (Vaheri et al., 2013).

Apodemus agrarius (host species for HTNV) and Rattus norvegicus [host species for Seoul virus (SEOV)] are the predominant reservoirs in the wild and in residential areas, respectively (Zhang S et al., 2014). Phylogenetic analysis shows that at least nine clades of HTNV and five clades of SEOV are prevalent in China (Huang et al., 2012; Zou et al., 2016), including the Xinyi and Fugong viruses that have been recently reported in specific epidemic foci (Ge et al., 2016; Gu et al., 2016). Rodent-borne hantaviruses have also been detected in Lao PDR, Thailand (Thailand hantavirus, THAIV) and Cambodia (THAIV-like virus) (Blasdell et al., 2011; Pattamadilok et al., 2006). Among those viruses, THAIV can cause disease in humans (Pattamadilok et al., 2006; Gamage et al., 2011). Epizootiology studies have reported the presence of rats in Vietnam and Singapore with antibodies against SEOV (Truong et al., 2009; Johansson et al., 2010). SEOV has also been detected in rodents from Indonesia (Ibrahim et al., 1996). In the Mekong Delta of Vietnam, rodents can be infected with DOBV and SEOV with a positive rate of $6.9 \%$ (Van Cuong et al., 2015). There have also been studies claiming that selenium deficiency is correlated with increased prevalence of hantavirus infections in both humans and rodents (Fang LQ et al., 2015).

The distribution of pathogenic hantaviruses is expanding, and the differences between the "Old World" and "New World" viruses are gradually becoming less obvious. Technological advancements in molecular biology make it possible for investigators to rapidly search and characterize newly discovered hantaviruses. So far, more than 50 hantavirus strains have been identified, and 24 of those strains are of pathogenic relevance to humans (Table 2). Other hantaviruses may remain undetected, as infections are likely to go unreported in many areas, particularly in Africa, the Middle East, Central America, the Indian subcontinent, and Mongolia.

Nonpathogenic hantaviruses and their reservoirs Many new strains of hantavirus have been identified with the discovery of the respective host species. Recent studies report that mites can transmit hantaviruses both by biting laboratory mice and vertically through the eggs to 
Table 2. Geographic distribution of pathogenic hantaviruses

\begin{tabular}{|c|c|c|c|c|}
\hline Virus isolate or strain & Abbreviation & $\begin{array}{l}\text { Associated } \\
\text { disease }\end{array}$ & Rodent host & Geographic distribution \\
\hline Amur virus (Zhang et al., 2013) & AMRV & HFRS & Apodemus peninsulae & Russia, China, Korea \\
\hline $\begin{array}{l}\text { Dobrava-Belgrade virus } \\
\text { (Papa, 2012) }\end{array}$ & DOBV & HFRS & Apodemus flavicollis & Europe (Balkans) \\
\hline Hantaan Virus (Jiang et al., 2016) & HTNV & HFRS & Apodemus agrarius & China, South Korea, Russia \\
\hline Puumala virus (Maes et al., 2004) & PUUV & $\begin{array}{l}\text { HFRS/NE/ } \\
\text { HCPS }\end{array}$ & $\begin{array}{l}\text { Clethrionomys glareolus } \\
\text { Myodes glareolus }\end{array}$ & Europe (Finland) \\
\hline $\begin{array}{l}\text { Saaremaa virus (Plyusnina } \\
\text { et al., 2009a) }\end{array}$ & SAAV & HFRS/NE & Apodemus agrarius & Europe \\
\hline Seoul virus (Yao et al., 2012) & SEOV & HFRS & Rattus norvegicus & Worldwide \\
\hline $\begin{array}{l}\text { Thailand hantavirus (Pattamadilok } \\
\text { et al., 2006; Gamage et al., 2011) }\end{array}$ & THAIV & HFRS & Bandicota indica & Thailand \\
\hline Tula virus (Nikolic et al., 2014) & TULV & HFRS & Microtus arvalis & Europe \\
\hline $\begin{array}{l}\text { Andes virus (Torres-Perez } \\
\text { et al., 2016) }\end{array}$ & ANDV & HCPS & $\begin{array}{l}\text { Oligoryzomys } \\
\text { longicaudatus }\end{array}$ & Argentina, Chile \\
\hline $\begin{array}{l}\text { Araraquara virus } \\
\text { (de Araujo et al., 2015) }\end{array}$ & ARAV & HCPS & Necromys lasiurus & Brazil \\
\hline $\begin{array}{l}\text { Bayou virus } \\
\text { (Holsomback et al., 2013) }\end{array}$ & BAYV & HCPS & Oryzomys palustris & North America \\
\hline $\begin{array}{l}\text { Bermejo virus } \\
\text { (Padula et al., 2002) }\end{array}$ & BMJV & HCPS & $\begin{array}{l}\text { Oligoryzomys chacoensis } \\
\text { Oligoryzomys flavescens }\end{array}$ & Argentina, Bolivia \\
\hline $\begin{array}{l}\text { Black Creek Canal virus } \\
\text { (Knust and Rollin, 2013) }\end{array}$ & BCCV & HCPS & Sigmodon hispidus & North America \\
\hline $\begin{array}{l}\text { Castelo Dos Sonhos virus } \\
\text { (Firth et al., 2012) }\end{array}$ & CASV & HCPS & Oligoryzomys spp.? & Brazil \\
\hline $\begin{array}{l}\text { Choclo virus } \\
\text { (Nelson et al., 2010) }\end{array}$ & $\mathrm{CHOV}$ & HCPS & Oligoryzomys fulvescens & Panama \\
\hline $\begin{array}{l}\text { Juquitiba virus } \\
\text { (Figueiredo et al., 2014) }\end{array}$ & JUQV & HCPS & Oligoryzomys nigripes & Argentina, Brazil \\
\hline $\begin{array}{l}\text { Laguna Negra virus } \\
\text { (Figueiredo et al., 2014) }\end{array}$ & LANV & HCPS & Calomys callosus & $\begin{array}{l}\text { Argentina, Paraguay, } \\
\text { Bolivia }\end{array}$ \\
\hline $\begin{array}{l}\text { Lechiguanas virus } \\
\text { (Guterres et al., 2015) }\end{array}$ & LECV & HCPS & Oligoryzomys flavescens & Argentina \\
\hline $\begin{array}{l}\text { Maciel virus } \\
\text { (Guterres et al., 2015) }\end{array}$ & MCLV & HCPS & Bolomys obscurus & Argentina \\
\hline $\begin{array}{l}\text { Monongahela virus } \\
\text { (Rhodes et al., 2000) }\end{array}$ & MGLV & HCPS & Peromyscus leucopus & North America \\
\hline $\begin{array}{l}\text { Muleshoe virus } \\
\text { (Rawlings et al., 1996) }\end{array}$ & MULEV & HCPS & Sigmodon hispidus & North America \\
\hline $\begin{array}{l}\text { New York virus } \\
\text { (Knust and Rollin, 2013) }\end{array}$ & NYV & HCPS & Peromyscus leucopus & North America \\
\hline $\begin{array}{l}\text { Oran virus } \\
\text { (Figueiredo et al., 2014) }\end{array}$ & ORNV & HCPS & Oligoryzomys chacoensis & Argentina \\
\hline $\begin{array}{l}\text { Sin Nombre virus (Brocato } \\
\text { et al., 2014) }\end{array}$ & SNV & HCPS & Peromyscus maniculatus & North America \\
\hline
\end{tabular}


their offspring. However, transmission from mites to humans has not been reported (Yu and Tesh, 2014). Hantaviruses have also been found in novel hosts, such as bats (Zhang YZ, 2014), Cricetulus griseus (Fang LZ et al., 2015), the stripe-backed shrew (Zuo et al., 2014), brown rat (Guo et al., 2016), and other small mammals, including Asian house shrews and house mice. Some of these hosts are closely associated with humans and inhabit areas in and around homes in China. The epidemiological significance of these unconventional hosts has not yet been defined. However, the threat of hantaviruses is of major concern, as it has been detected in pet rats in the United Kingdom and in Sweden (McElhinney et al., 2016).

Some recently discovered hantaviruses, such as the Muju virus (MUJV) detected in the royal vole (also known as the Korean red-backed vole; Myodes regulus), and the Imjin (MJNV) and Jeju viruses (JJUV) in the shrew and bat, have been reported in Korea (Lee et al., 2014). The hantavirus genome referred to as the Asama virus (ASAV) has been detected in the Japanese shrew mole (Urotrichus talpoides) (Arai et al., 2008). Hantavirus sequences have also been recovered from an Asian house rat (Rattus tanezumi) captured in Indonesia (Plyusnina et al., 2009b). A bat-borne hantavirus (Xuan Son virus, XSV) has been reported in Vietnam (Arai et al., 2013). Since 2007, non-rodent hosts of hantaviruses (mainly shrews and moles) have been reported in Europe. Three distinct hantaviruses have also been discovered in wild rodents in Mexico. However, whether these viruses cause human disease remains unclear.

Hantavirus was first detected in Africa following PCR analysis in 2006. The virus was called the Sangassou virus (SANGV) and although the positive rate was relatively low, it was detected in the African wood mouse ( $\mathrm{Hy}$ lomyscus simus) in a forested habitat in Guinea (Klempa et al., 2006). Since then, several other shrew-borne hantaviruses have been identified in Africa. For example, Tanganya virus (TGNV) was detected in Therese's shrew (Crocidura theresae); Azagny virus (AZGV), in the West African pygmy shrew (Crocidura obscurior) in Côte d'Ivoire; and Bowé virus (BOWV), in Doucet's musk shrew (Crocidura douceti) in southwestern Guinea. Tigray virus (TIGV), the first hantavirus reported in Eastern Africa, was discovered in Ethiopia (Witkowski et al., 2014). With the exception of SANGV, which was first isolated in cell culture in 2012 (Klempa et al., 2012), the aforementioned species were all detected by PCR, and are not yet approved as new viral species (Witkowski et al., 2014).

New types of hantavirus are still being discovered in Africa. The host diversity of hantaviruses on the African continent has challenged the view that hantaviruses are predominantly rodent-borne viruses. Several shrew- borne, and the first bat-borne hantaviruses (Magboi virus, MGBV) have been reported in Africa. Kilimanjaro (KILV) and Uluguru viruses (ULUV) have been reported in shrews of the genus Myosorex (M. zinki and $M$. geata) in Tanzania. As natural reservoirs of hantaviruses, surveillance and monitoring of the bat population might facilitate efficient pathogen maintenance and spread, as bats can travel over comparatively longer distances (Weiss et al., 2012). The serological and ecological aspects, as well as the clinical significance of many viruses still need to be considered. However, evidence has emerged of human infections with shrew-borne hantaviruses in Côte d'Ivoire and Gabon (Heinemann et al., 2016).

\section{EPIDEMIOLOGY AND EPIZOOTIOLOGY OF HANTAVIRUS INFECTION}

\section{Asian-Pacific countries}

The incidence of HFRS varies geographically (Figure 1). In China, HFRS is classified as a class B notifiable disease (Zou et al., 2016) and is considered a severe public health challenge (Zhang WY et al., 2014; Jiang et al., 2016). HTNV and SEOV are the major causes of HFRS (Song, 1999; Zhang S et al., 2014). So far, HFRS cases have been reported in 30 out of 32 provinces in China (excluding Hong Kong, Macao, and Taiwan) (Zhang S et al., 2014). Several provinces in northeastern China exhibit the highest overall risk (Zhang WY et al., 2014). Nine provinces with the highest incidence account for $84.16 \%$ of the total number of cases. A total of 112,177 cases and 1,116 deaths have been reported over the past ten years in China (Zhang S et al., 2014; Papa et al., 2016). Over 10,000 HFRS cases were reported nationwide in 2014 and 2015 , and the fatality rates were $0.68 \%$ and $0.60 \%$ in 2014 and 2015, respectively. According to the most recent data, China accounted for about $40 \%-$ $50 \%$ of all HFRS cases worldwide during the same period.

Asian Russia is another area affected by hantavirus infections. In 1934, the first case of HFRS was reported in the Khabarovsk region. Asian Russia accounted for 3,145 HFRS cases between 1978 and 1995, with a morbidity of $1.7 \%$ (Onishchenko and Ezhlova, 2013). Viruses in Asian Russia show great similarity to those in China and Korea (Onishchenko and Ezhlova, 2013), and PUUV has been found in Far Eastern Russia.

In Korea, where HTNV was first isolated, 300-500 HFRS cases are reported annually with a mean case fatality rate of $1 \%$. Farmers account for the largest proportion of HFRS $(35.6 \%)$ cases, most of which were detected during the months of October, November, and December (Lee et al., 2013; Noh et al., 2013). Although HTNV is the main cause of HFRS in Korea, SEOV (the second most significant cause) is predominant in Korea 


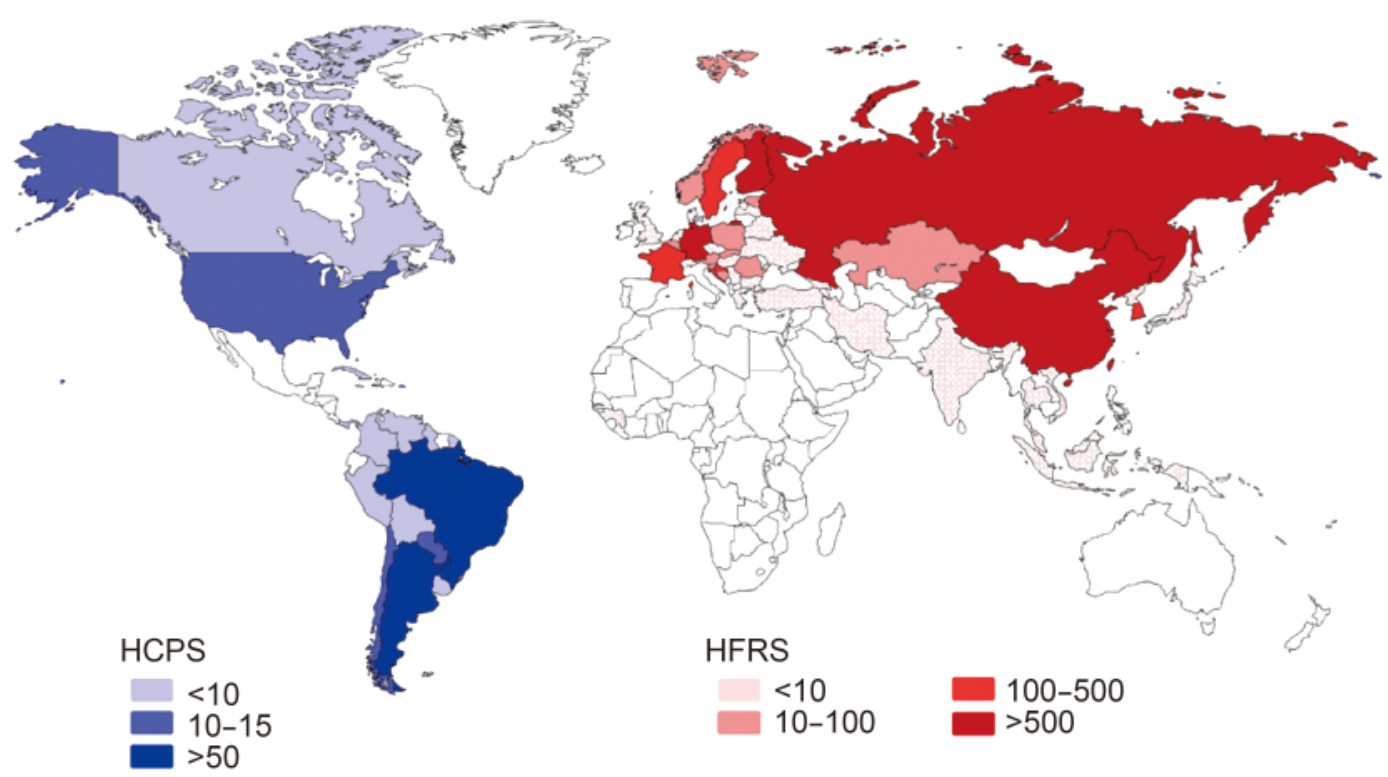

Figure 1. Geographical representation of approximate incidence of hantavirus cardiopulmonary syndrome (HCPS) and hemorrhagic fever with renal syndrome (HFRS) by country per year (data updated to 2016).

(Noh et al., 2013). Some acute-phase cases in Korea have shown a higher IgM antibody titer to PUUV than to HTNV, despite the fact that PUUV has not been detected in Korea (Noh et al., 2013). In North Korea, literature on hantaviruses is scarce. A study in China reported a relatively high rate of SEOV infection in $R$. norvegicus rats $(16.8 \%)$ in the city of Hyesan, North Korea (Yao et al., 2013).

No new HFRS cases have been reported over the past 25 years in Japan. However, anti-hantavirus antibodies have been detected in several rodent species, such as Apodemus speciosus, $R$. norvegicus and Clethrionomys rufocanus, and one member of the Japan Ground SelfDefense Force on Hokkaido tested positive for hantavirus antibodies (Lokugamage et al., 2004). Laboratory rats have been responsible for 126 HFRS cases, including one death (Kariwa et al., 2007).

In Vietnam, Singapore, and Thailand, a small number of HFRS cases have been reported showing symptoms that are consistent with HFRS and high titers of hantavirusreactive IgM and IgG (Wong et al., 1985; Suputthamongkol et al., 2005; Huong et al., 2010). SEOV infection, like dengue fever, has also been reported in Malaysia (Hamidon and Saadiah, 2003). Serological evidence of hantavirus infections in humans, particularly in patients with fever of unknown origin, has been reported in Vietnam, Singapore, Laos, Thailand, Malaysia, and Indonesia (Rollin et al., 1986; Lam et al., 2001; Groen et al., 2002; Truong et al., 2009). In Thailand, cases of coinfection with hantavirus and leptospirosis have been detected (Gamage et al., 2011). HTNV infection during a dengue outbreak has also been reported in Indonesia (Suharti et al., 2009).

In southern Asia, specifically in India and Sri Lanka, HFRS cases have been reported (Vitarana et al., 1988; Chandy et al., 2009), including those of co-infection with leptospirosis and hantavirus (Sunil-Chandra et al., 2015). However, many patients with fever of unknown origin and individuals in contact with rodents show positive test results for the HTNV antibody (Chandy et al., 2008). If clinical diagnostic methods are improved, a greater number of HFRS cases might be discovered in India. Hantavirus has also been detected in Nepal in the Asian house shrew (Suncus murinus, Thottapalayam virus) (Kang et al., 2011). It is reasonable to assume that undiagnosed cases of hantavirus infection might exist in Nepal, owing to its geographical position.

\section{European countries}

Over 3,000 HFRS cases are diagnosed annually in Europe (excluding an additional 5,000-10,000 cases annually in Russia) and this number continues to increase steadily (Heyman et al., 2011). In Northern Europe, human HFRS epidemics have a cycle of 3-4 years, as the rodent population changes. The pathogen responsible for HFRS varies across Europe.

Most PUUV-associated cases have been diagnosed in European Russia, Finland, Sweden, France, Germany, and the Balkans. Finland has recorded the highest number of HFRS cases in the European Union (Heyman et al., 2011). The first case of NE in Switzerland was reported in 2008 (Fontana-Binard et al., 2008), and the first 
molecular evidence of PUUV infection was discovered in Poland in 2014 (Ali et al., 2014). The last PUUV outbreak occurred in 2012 in Germany, with over 2,800 cases (Kruger et al., 2013). Latvia has also reported HFRS cases. Some countries, such as Greece and Hungary, have a high seroprevalence of hantavirus among healthy residents. Hantavirus antibodies have also been detected through sero-epidemiological surveys in Italy (Kallio-Kokko et al., 2006), Lithuania (Sandmann et al., 2005), and Spain (Lledo et al., 2003b). However, no clinical cases have been diagnosed in these countries. Nevertheless, imported HCPS was detected in an Italian traveler returning from Cuba (Rovida et al., 2013), and an imported NE case has also been reported in Spain (Lledo et al., 2003a).

DOBV infection is predominantly found in SouthEastern Europe. DOBV has been the cause of almost all cases of HFRS in Greece. DOBV is the most life-threatening hantavirus in Europe, with a case fatality rate of $12 \%$. It is responsible for almost all fatal cases of HFRS in Europe (Papa, 2012). Most cases of DOBV-HFRS have been reported in the Balkans and in Russia. The prototype of DOBV is known as DOBV-Af, as it is associated with Apodemus flavicollis. A DOBV variant, Sochi subtype, known as DOBV-Ap (associated with Apodemus ponticus) causes severe human infection in the Black Sea coast region of Russia (Klempa et al., 2008). Another DOBV-like virus, referred to as SAAV or DOBV-Aa, was recovered from Apodemus agrarius on the Saaremaa island of Estonia (Papa, 2012). SAAV infection was confirmed in three HFRS patients.

The co-existence of PUUV and DOBV has also been observed, especially in the Balkans, where severe DOBV cases have been identified from Slovenia in the north to Greece in the south, and PUUV infections detected in the northern part of the Balkans. DOBV-Af is the main pathogen of HFRS in the Balkans. Furthermore, DOBVAa has contributed to outbreaks in European Russia and Germany. Cases of DOBV infection also exist in Turkey (where cases of PUUV infection have also been reported), Poland, the Czech Republic, Lithuania, and Latvia (Papa, 2012; Avsic Zupanc et al., 2014).

Besides PUUV and DOBV, TULV-associated human infections have been reported in the Czech Republic, Switzerland, and Germany (Klempa et al., 2003; Zelena et al., 2013). Human SEOV infections have also been reported in the United Kingdom (Atkinson et al., 2015). In addition, SEOV infection has been reported in a pregnant woman in France (Mace et al., 2013). HCPS has been reported in individuals traveling to Europe from the New World.

\section{American countries}

In the United States, HCPS has been listed among the notifiable diseases since 1995 (Knust and Rollin, 2013). However, several cases of SNV infections have only been reported in Canada thus far. During the period 1993-2013, 624 cases of HCPS have been reported in the United States. Among these cases, 96\% occurred in states west of the Mississippi River, most of which were infected with SNV. HCPS could also be caused by Bayou virus (BAYV), Black Creek Canal virus (BCCV), Monongahela virus (MGLV), and New York virus (NYV). HFRS cases caused by SEOV have also been documented.

In Central America, hantavirus is an important, but often neglected, rodent-borne tropical disease. In Panama, Choclo virus (CHOV) has been linked to HCPS, but is also linked to mild or asymptomatic illness without pulmonary findings (Hotez et al., 2014). In one area of western Panama, the antibody prevalence among more than 1,000 individuals was as high as $60 \%$, and those who showed seroconversion outnumbered those with pulmonary syndrome by 14 to 1 (Hotez et al., 2014).

In Argentina, about 100-200 HCPS cases are reported annually. Most cases occur in the spring and summer near forested areas. Chile has recorded 837 cases of HCPS during 2013, with a fatality rate of $36.1 \%$. Most cases occur between November and April, and are caused mainly by ANDV. Brazil reported 1,600 HCPS cases before 2013; however, the number of seropositive individuals is estimated to be much greater. The etiologic agents of HCPS in Brazil are complex, and include at least seven genotypes. Studies in Brazil have shown that Araraquara virus (ARAV) is one of the most virulent hantaviruses that can induce HCPS, with a case fatality rate of 50\% (Figueiredo et al., 2014).

Cases of HCPS, as well as serological evidence of hantavirus infections have been discovered in Bolivia, Colombia, French Guiana, Peru, Uruguay, Paraguay, and Venezuela. Furthermore, serological evidence of hantavirus infection has also been detected in Suriname (Armien et al., 2013; Figueiredo et al., 2014; Goeijenbier et al., 2015). One imported HFRS case has been reported in Ecuador (Demeester et al., 2010). Risk factors of HCPS in South America include being of the male gender, engaging in outdoor activities and residing in rural areas (Manigold and Vial, 2014). With the rapid expansion of cities in South America and increased development in agriculture, hantavirus infectious are expected to show a steady increase.

\section{African and Middle-Eastern countries}

Africa has long been neglected in terms of hantavirus research, and no indigenous African hantaviruses were identified before 2006. Within recent years, new discoveries in hantavirus epizootiology and epidemiology have been made, and over 10 hantaviruses have now been 
identified in Africa. When compared to Asia and Europe, animal hosts in Africa show greater diversity (Witkowski et al., 2014). Serological evidence of HTNV and SEOV infections has long been found in Africa, especially in patients with fever (Witkowski et al., 2014).

The Guinean Forest block, where the first hantavirus in Africa was found, is recognized as a hantavirus endemic region (Witkowski et al., 2014). Serological studies in Forest Guinea reported that $1.2 \%$ of the tested individuals were positive (Klempa et al., 2010). A similar study from Sangassou village, Guinea on febrile patients with renal or respiratory failure and bleeding, reported a seroprevalence of $4.4 \%$ (Klempa et al., 2010). The first hantavirus-associated human disease in Africa was also reported in Guinea, with a high anti-hantavirus IgM antibody titer and stable IgG antibody titer (Klempa et al., 2010).

There is also evidence of hantavirus infection in other African countries. In a serological study in the South African Cape Region, seroprevalence was 1.0\% (Witkowski et al., 2014). However, no case of hantavirus-associated human disease has been diagnosed in Southern Africa. A recent cross-sectional seroprevalence study in Côte d'Ivoire and the Democratic Republic of the Congo reported seroprevalence rates of $3.9 \%$ and $2.4 \%$, respectively (Witkowski et al., 2015). These data indicate that hantavirus infections have probably been underestimated in Africa.

Hantavirus is seldom found in the Middle East. In Egypt however, seroprevalence of hantavirus has been reported among patients with chronic renal failure, all of whom had been exposed to rodents (Botros et al., 2004). In Israeli patients with renal failure, antibodies to HTNV and PUUV were detected (George et al., 1998). HFRS patients in Iran were first described in 1966 (Ardalan et al., 2014). These results provide evidence that hantavirus does indeed exist in the Middle East. In addition, seroprevalence of hantavirus has been reported in UK military personnel deployed in Afghanistan (Newman et al., 2014).

\section{CLIMATE CHANGE AND HANTAVIRUS INFECTION}

Climate change is an important factor that might affect the geographic distribution, abundance, and dynamics of rodent hosts. Therefore, climate change could affect the epidemiology of hantavirus infections. One study suggests that when animal hosts expand their territory, the chances of hantavirus infection in other susceptible rodents are increased. The researchers refer to this phenomenon as "host expansion" and it has been observed with HTNV and SEOV in China (Fang LZ et al., 2015).
Climate change influences temperature, rainfall and humidity globally, and through its effects on the host species, can thus affect hantaviruses. The 1992-1993 El Nino phenomenon increased rainfall in the United States, and thereby enhanced food supply to rodents that correlated with an outbreak of HCPS in 1993 (Gubler et al., 2001). The effects of global warming are evident in western and central Europe, where seed production of oak and beech is increased. This provides a rich food supply to promote survival of rodents during the winter, which further gives rise to PUUV-associated NE outbreaks (Klempa, 2009). North Atlantic Oscillation, another phenomenon of global warming, leads to a reduction in protective snow cover for rodents in Scandinavia (Klempa, 2009). Air pollution has been positively correlated with the incidence of HFRS in Korea from 2001 to 2010 (Han et al., 2013).

Climate change also affects human activities and might alter the frequency of contact between humans and hantaviruses. The increased incidence of extreme climatic events, such as floods, drought or hurricanes could facilitate human-rodent contact, which could have played a role in the outbreak of PUUV in Sweden (Pettersson et al., 2008). Agricultural activity could also increase the prevalence of hantavirus in rodents of Southeast Asia (Blasdell et al., 2016). Further studies to discover the potential host switch and expansion of HTNV under the pressure of climate change and human activity are necessary.

\section{CONCLUSIONS}

Epidemiological studies have shown that hantaviruses are widely distributed globally, in both humans and animals. The ecology of hantaviruses and their native hosts is complex, and our understanding of virus-host interactions remains incomplete. A better understanding of hantavirus ecology and epidemiology would be beneficial in the control of hantavirus-associated diseases in humans.

With the implementation of intervention measures, the incidence of hantavirus infections seems to have shown a decline in recent years in Asian countries. In China and Korea, the number of HFRS cases has been drastically reduced, even though new strains of hantavirus are continually being discovered. In theory, the geographical environment of Mongolia, Mexico and North Korea is suitable for growth of the host species, and this should be indicative of the epidemic-prone areas of hantavirus. However, there have only been a few cases reported in these countries. It is possible that a greater number of hantavirus cases would be reported if advanced testing techniques are utilized in these areas. 


\section{ACKNOWLEDGMENTS}

The authors would like to thank Mr. An Yang from the Department of Foreign Languages, Fourth Military Medical University, China, for improving the English manuscript. This work was supported by the National Natural Science Foundation of China (No. 81373118) and the National Basic Research Programme of China (973 Programme No. 2012CB518905).

\section{COMPLIANCE WITH ETHICAL GUIDELINES}

The authors declare that they have no conflict of interest. This article does not contain any studies with human or animal subjects performed by any of the authors.

\section{REFERENCES}

Ali HS, Drewes S, Sadowska ET, Mikowska M, Groschup MH, Heckel G, Koteja P, Ulrich RG. 2014. First molecular evidence for Puumala hantavirus in Poland. Viruses, 6: 340-353.

Arai S, Nguyen ST, Boldgiv B, Fukui D, Araki K, Dang CN, Ohdachi SD, Nguyen NX, Pham TD, Boldbaatar B, Satoh H, Yoshikawa Y, Morikawa S, Tanaka-Taya K, Yanagihara R, Oishi K. 2013. Novel bat-borne hantavirus, Vietnam. Emerg Infect Dis, 19: 1159-1161.

Arai S, Ohdachi SD, Asakawa M, Kang HJ, Mocz G, Arikawa J, Okabe N, Yanagihara R. 2008. Molecular phylogeny of a newfound hantavirus in the Japanese shrew mole (Urotrichus talpoides). Proc Natl Acad Sci U S A, 105: 16296-16301.

Ardalan M, Chinikar S, Mohajel Shoja M. 2014. Hemorrhagic Fever with renal syndrome and its history in Iran. Iran J Kidney Dis, 8: 438-442.

Armien B, Pascale JM, Bayard V, Munoz C, Mosca I, Guerrero G, Armien A, Quiroz E, Castillo Z, Zaldivar Y, Gracia F, Hjelle B, Koster F. 2004. High seroprevalence of hantavirus infection on the Azuero peninsula of Panama. Am J Trop Med Hyg, 70: 682-687.

Armien B, Pascale JM, Munoz C, Marinas J, Nunez H, Herrera M, Trujillo J, Sanchez D, Mendoza Y, Hjelle B, Koster F. 2013. Hantavirus fever without pulmonary syndrome in Panama. Am J Trop Med Hyg, 89: 489-494.

Atkinson B, Jameson LJ, Bovill BA, Aarons EJ, Clewlow J, Lumley S, Latham J, Jenkins MH, MacGowan AP, Simpson AJ, Ahmed J, Brooks TJ, Hewson R. 2015. A non-fatal case of hantavirus cardiopulmonary syndrome imported into the UK (ex Panama), July 2014. J Clin Virol, 67: 52-55.

Avsic Zupanc T, Korva M, Markotic A. 2014. HFRS and hantaviruses in the Balkans/South-East Europe. Virus Res, 187: 27-33.

Blasdell K, Cosson JF, Chaval Y, Herbreteau V, Douangboupha B, Jittapalapong S, Lundqvist A, Hugot JP, Morand S, Buchy P. 2011. Rodent-borne hantaviruses in Cambodia, Lao PDR, and Thailand. Ecohealth, 8: 432-443.

Blasdell K, Morand S, Henttonen H, Tran A, Buchy P. 2016. Hantavirus seropositivity in rodents in relation to habitat heterogeneity in human-shaped landscapes of Southeast Asia. Spat Spatiotemporal Epidemiol, 17: 27-35.

Botros BA, Sobh M, Wierzba T, Arthur RR, Mohareb EW, Frenck R, El Refaie A, Mahmoud I, Chapman GD, Graham RR. 2004. Prevalence of hantavirus antibody in patients with chronic renal disease in Egypt. Trans R Soc Trop Med Hyg, 98: 331-336.

Brocato RL, Hammerbeck CD, Bell TM, Wells JB, Queen LA,
Hooper JW. 2014. A lethal disease model for hantavirus pulmonary syndrome in immunosuppressed Syrian hamsters infected with Sin Nombre virus. J Virol, 88: 811-819.

Chandy S, Boorugu H, Chrispal A, Thomas K, Abraham P, Sridharan G. 2009. Hantavirus infection: a case report from India. Indian J Med Microbiol, 27: 267-270.

Chandy S, Yoshimatsu K, Ulrich RG, Mertens M, Okumura M, Rajendran P, John GT, Balraj V, Muliyil J, Mammen J, Abraham P, Arikawa J, Sridharan G. 2008. Seroepidemiological study on hantavirus infections in India. Trans R Soc Trop Med Hyg, 102: 70-74.

de Araujo J, Dure AI, Negrao R, Ometto T, Thomazelli LM, Durigon EL. 2015. Co-circulation in a single biome of the Juquitiba and Araraquara hantavirus detected in human sera in a sub-tropical region of Brazil. J Med Virol, 87: 725-732.

Demeester R, Bottieau E, Van Esbroeck M, Pourkarim MR, Maes P, Clement J. 2010. Hantavirus nephropathy as a pseudo-import pathology from Ecuador. Eur J Clin Microbiol Infect Dis, 29: 59-62.

Fang LQ, Goeijenbier M, Zuo SQ, Wang LP, Liang S, Klein SL, Li XL, Liu K, Liang L, Gong P, Glass GE, van Gorp E, Richardus JH, Ma JQ, Cao WC, de Vlas SJ. 2015. The association between hantavirus infection and selenium deficiency in mainland China. Viruses, 7: 333-351.

Fang LZ, Zhao L, Wen HL, Zhang ZT, Liu JW, He ST, Xue ZF, Ma DQ, Zhang XS, Zhang Y, Yu XJ. 2015. Reservoir host expansion of hantavirus, China. Emerg Infect Dis, 21: 170-171.

Ferrer JF, Galligan D, Esteban E, Rey V, Murua A, Gutierrez S, Gonzalez L, Thakuri M, Feldman L, Poiesz B, Jonsson C. 2003. Hantavirus infection in people inhabiting a highly endemic region of the Gran Chaco territory, Paraguay: association with Trypanosoma cruzi infection, epidemiological features and haematological characteristics. Ann Trop Med Parasitol, 97: 269-280.

Figueiredo LT, Souza WM, Ferres M, Enria DA. 2014. Hantaviruses and cardiopulmonary syndrome in South America. Virus Res, 187: 43-54.

Firth C, Tokarz R, Simith DB, Nunes MR, Bhat M, Rosa ES, Medeiros DB, Palacios G, Vasconcelos PF, Lipkin WI. 2012. Diversity and distribution of hantaviruses in South America. J Virol, 86: 13756-13766.

Fontana-Binard L, Schultze D, Rojanavisut BS, Kruger DH, Dollenmaier G, Zanetti G, Meylan P. 2008. First case of nephropathia epidemica acquired in Switzerland. Rev Med Suisse, 4: 1572-1575. (In French)

Gamage CD, Yasuda SP, Nishio S, Kularatne SA, Weerakoon K, Rajapakse J, Nwafor-Okoli C, Lee RB, Obayashi Y, Yoshimatsu K, Arikawa J, Tamashiro H. 2011. Serological evidence of Thailand virus-related hantavirus infection among suspected leptospirosis patients in Kandy, Sri Lanka. Jpn J Infect Dis, 64: $72-75$.

Ge XY, Yang WH, Pan H, Zhou JH, Han X, Zhu GJ, Desmond JS, Daszak P, Shi ZL, Zhang YZ. 2016. Fugong virus, a novel hantavirus harbored by the small oriental vole (Eothenomys eleusis) in China. Virol J, 13: 27.

George J, Patnaik M, Bakshi E, Levy Y, Ben-David A, Ahmed A, Peter JB, Shoenfeld Y. 1998. Hantavirus seropositivity in Israeli patients with renal failure. Viral Immunol, 11: 103-108.

Goeijenbier M, Aron G, Anfasa F, Lundkvist A, Verner-Carlsson J, Reusken CB, Martina BE, van Gorp EC, Resida L. 2015. Emerging Viruses in the Republic of Suriname: Retrospective and Prospective Study into Chikungunya Circulation and Suspicion of Human Hantavirus Infections, 2008-2012 and 2014. Vector Borne Zoonotic Dis, 15: 611-618.

Groen J, Suharti C, Koraka P, van Gorp EC, Sutaryo J, Lundkvist A, Osterhaus AD. 2002. Serological evidence of human hantavirus infections in Indonesia. Infection, 30: 326-327. 
Gu SH, Arai S, Yu HT, Lim BK, Kang HJ, Yanagihara R. 2016. Genetic variants of Cao Bang hantavirus in the Chinese mole shrew (Anourosorex squamipes) and Taiwanese mole shrew (Anourosorex yamashinai). Infect Genet Evol, 40: 113-118.

Gubler DJ, Reiter P, Ebi KL, Yap W, Nasci R, Patz JA. 2001. Climate variability and change in the United States: potential impacts on vector- and rodent-borne diseases. Environ Health Perspect, 109 Suppl 2: 223-233.

Guo G, Sheng J, Wu X, Wang Y, Guo L, Zhang X, Yao H. 2016. Seoul virus in the Brown Rat ( Rattus norvegicus ) from Urumqi, Xinjiang, Northwest of China. J Wildl Dis, 52: 705-708.

Guterres A, de Oliveira RC, Fernandes J, Schrago CG, de Lemos ER. 2015. Detection of different South American hantaviruses. Virus Res, 210: 106-113.

Hall PR, Leitao A, Ye C, Kilpatrick K, Hjelle B, Oprea TI, Larson RS. 2010. Small molecule inhibitors of hantavirus infection. Bioorg Med Chem Lett, 20: 7085-7091.

Hamidon BB, Saadiah S. 2003. Seoul hantavirus infection mimicking dengue fever. Med J Malaysia, 58: 786-787.

Han SS, Kim S, Choi Y, Kim S, Kim YS. 2013. Air pollution and hemorrhagic fever with renal syndrome in South Korea: an ecological correlation study. BMC Public Health, 13: 347.

Heinemann P, Tia M, Alabi A, Anon JC, Auste B, Essbauer S, Gnionsahe A, Kigninlman H, Klempa B, Kraef C, Kruger N, Leendertz FH, Ndhatz-Sanogo M, Schaumburg F, Witkowski PT, Akoua-Koffi CG, Kruger DH. 2016. Human infections by non-rodent associated hantaviruses in Africa. J Infect Dis, 214: $1507-1511$.

Heyman P, Ceianu CS, Christova I, Tordo N, Beersma M, Joao Alves M, Lundkvist A, Hukic M, Papa A, Tenorio A, Zelena H, Essbauer S, Visontai I, Golovljova I, Connell J, Nicoletti L, Van Esbroeck M, Gjeruldsen Dudman S, Aberle SW, Avsic-Zupanc T, Korukluoglu G, Nowakowska A, Klempa B, Ulrich RG, Bino S, Engler O, Opp M, Vaheri A. 2011. A five-year perspective on the situation of haemorrhagic fever with renal syndrome and status of the hantavirus reservoirs in Europe, 2005-2010. Euro Surveill, 16. pii: 19961.

Holsomback TS, Van Nice CJ, Clark RN, McIntyre NE, Abuzeineh AA, Salazar-Bravo J. 2013. Socio-ecology of the marsh rice rat (Oryzomys palustris) and the spatio-temporal distribution of Bayou virus in coastal Texas. Geospat Health, 7: 289-298.

Hotez PJ, Woc-Colburn L, Bottazzi ME. 2014. Neglected tropical diseases in Central America and Panama: review of their prevalence, populations at risk and impact on regional development. Int J Parasitol, 44: 597-603.

Huang LY, Zhou H, Yin WW, Wang Q, Sun H, Ding F, Man TF, Li Q, Feng ZJ. 2012. The current epidemic situation and surveillance regarding hemorrhagic fever with renal syndrome in China, 2010. Zhonghua Liu Xing Bing Xue Za Zhi, 33: 685-691. (In Chinese)

Huggins JW, Hsiang CM, Cosgriff TM, Guang MY, Smith JI, Wu ZO, LeDuc JW, Zheng ZM, Meegan JM, Wang QN, et al. 1991. Prospective, double-blind, concurrent, placebo-controlled clinical trial of intravenous ribavirin therapy of hemorrhagic fever with renal syndrome. J Infect Dis, 164: 1119-1127.

Huong VT, Yoshimatsu K, Luan VD, Tuan le V, Nhi L, Arikawa J, Nguyen TM. 2010. Hemorrhagic fever with renal syndrome, Vietnam. Emerg Infect Dis, 16: 363-365.

Ibrahim IN, Sudomo M, Morita C, Uemura S, Muramatsu Y, Ueno H, Kitamura T. 1996. Seroepidemiological survey of wild rats for Seoul virus in Indonesia. Jpn J Med Sci Biol, 49: 69-74.

Jiang H, Du H, Wang LM, Wang PZ, Bai XF. 2016. Hemorrhagic Fever with Renal Syndrome: Pathogenesis and Clinical Picture. Front Cell Infect Microbiol, 6: 1.

Jiang W, Wang PZ, Yu HT, Zhang Y, Zhao K, Du H, Bai XF.
2014. Development of a SYBR Green I based one-step real-time PCR assay for the detection of Hantaan virus. J Virol Methods, 196: 145-151.

Johansson P, Yap G, Low HT, Siew CC, Kek R, Ng LC, Bucht G. 2010. Molecular characterization of two hantavirus strains from different rattus species in Singapore. Virol J, 7: 15.

Jonsson CB, Figueiredo LT, Vapalahti O. 2010. A global perspective on hantavirus ecology, epidemiology, and disease. Clin Microbiol Rev, 23: 412-441.

Kallio-Kokko H, Laakkonen J, Rizzoli A, Tagliapietra V, Cattadori I, Perkins SE, Hudson PJ, Cristofolini A, Versini W, Vapalahti O, Vaheri A, Henttonen H. 2006. Hantavirus and arenavirus antibody prevalence in rodents and humans in Trentino, Northern Italy. Epidemiol Infect, 134: 830-836.

Kang HJ, Kosoy MY, Shrestha SK, Shrestha MP, Pavlin JA, Gibbons RV, Yanagihara R. 2011. Short report: Genetic diversity of Thottapalayam virus, a Hantavirus harbored by the Asian house shrew (Suncus murinus) in Nepal. Am J Trop Med Hyg, 85: 540-545.

Kariwa H, Yoshimatsu K, Arikawa J. 2007. Hantavirus infection in East Asia. Comp Immunol Microbiol Infect Dis, 30: 341356.

Klempa B. 2009. Hantaviruses and climate change. Clin Microbiol Infect, 15: 518-523.

Klempa B, Fichet-Calvet E, Lecompte E, Auste B, Aniskin V, Meisel H, Denys C, Koivogui L, ter Meulen J, Kruger DH. 2006. Hantavirus in African wood mouse, Guinea. Emerg Infect Dis, 12: 838-840.

Klempa B, Koivogui L, Sylla O, Koulemou K, Auste B, Kruger $\mathrm{DH}$, ter Meulen J. 2010. Serological evidence of human hantavirus infections in Guinea, West Africa. J Infect Dis, 201: 1031-1034.

Klempa B, Meisel H, Rath S, Bartel J, Ulrich R, Kruger DH. 2003. Occurrence of renal and pulmonary syndrome in a region of northeast Germany where Tula hantavirus circulates. J Clin Microbiol, 41: 4894-4897.

Klempa B, Tkachenko EA, Dzagurova TK, Yunicheva YV, Morozov VG, Okulova NM, Slyusareva GP, Smirnov A, Kruger DH. 2008. Hemorrhagic fever with renal syndrome caused by 2 lineages of Dobrava hantavirus, Russia. Emerg Infect Dis, 14: 617-625.

Klempa B, Witkowski PT, Popugaeva E, Auste B, Koivogui L, Fichet-Calvet E, Strecker T, Ter Meulen J, Kruger DH. 2012. Sangassou virus, the first hantavirus isolate from Africa, displays genetic and functional properties distinct from those of other murinae-associated hantaviruses. J Virol, 86: 3819-3827.

Knust B, Rollin PE. 2013. Twenty-year summary of surveillance for human hantavirus infections, United States. Emerg Infect Dis, 19: 1934-1937.

Krautkramer E, Zeier M, Plyusnin A. 2013. Hantavirus infection: an emerging infectious disease causing acute renal failure. Kidney Int, 83: 23-27.

Kruger DH, Schonrich G, Klempa B. 2011. Human pathogenic hantaviruses and prevention of infection. Hum Vaccin, 7: 685-693.

Kruger DH, Ulrich RG, Hofmann J. 2013. Hantaviruses as zoonotic pathogens in Germany. Dtsch Arztebl Int, 110: 461-467.

Ksiazek TG, Peters CJ, Rollin PE, Zaki S, Nichol S, Spiropoulou C, Morzunov S, Feldmann H, Sanchez A, Khan AS, et al. 1995. Identification of a new North American hantavirus that causes acute pulmonary insufficiency. Am J Trop Med Hyg, 52: 117-123.

Lam SK, Chua KB, Myshrall T, Devi S, Zainal D, Afifi SA, Nerome K, Chu YK, Lee HW. 2001. Serological evidence of hantavirus infections in Malaysia. Southeast Asian J Trop Med Public Health, 32: 809-813. 
Latus J, Kitterer D, Segerer S, Artunc F, Alscher MD, Braun N. 2015a. Severe thrombocytopenia in hantavirus-induced nephropathia epidemica. Infection, 43: 83-87.

Latus J, Schwab M, Tacconelli E, Pieper FM, Wegener D, Rettenmaier B, Schwab A, Hoffmann L, Dippon J, Muller S, Fritz P, Zakim D, Segerer S, Kitterer D, Kimmel M, Gussmann K, Priwitzer M, Mezger B, Walter-Frank B, Corea A, Wiedenmann A, Brockmann S, Pohlmann C, Alscher MD, Braun N. 2015b. Acute kidney injury and tools for risk-stratification in 456 patients with hantavirus-induced nephropathia epidemica. Nephrol Dial Transplant, 30: 245-251.

Lee HW, Lee PW, Johnson KM. 1978. Isolation of the etiologic agent of Korean Hemorrhagic fever. J Infect Dis, 137: 298-308.

Lee JG, Gu SH, Baek LJ, Shin OS, Park KS, Kim HC, Klein TA, Yanagihara R, Song JW. 2014. Muju virus, harbored by Myodes regulus in Korea, might represent a genetic variant of Puumala virus, the prototype arvicolid rodent-borne hantavirus. Viruses, 6: 1701-1714.

Lee SH, Chung BH, Lee WC, Choi IS. 2013. Epidemiology of hemorrhagic fever with renal syndrome in Korea, 2001-2010. J Korean Med Sci, 28: 1552-1554.

Lledo L, Gegundez MI, Martinez JC, Sanfeliu I. 2003a. Epidemic nephropathy in Spain: first imported case. Med Clin (Barc), 121: 677.(In Spanish)

Lledo L, Klingstrom J, Gegundez MI, Plyusnina A, Vapalahti O, Saz JV, Beltran M, Sjolander KB, Vaheri A, Plyusnin A, Lundkvist A. 2003b. Hantavirus infections in Spain: analysis of sera from the general population and from patients with pneumonia, renal disease and hepatitis. J Clin Virol, 27: 296-307.

Lokugamage N, Kariwa H, Lokugamage K, Iwasa MA, Hagiya T, Yoshii K, Tachi A, Ando S, Fukushima H, Tsuchiya K, Iwasaki T, Araki K, Yoshimatsu K, Arikawa J, Mizutani T, Osawa K, Sato H, Takashima I. 2004. Epizootiological and epidemiological study of hantavirus infection in Japan. Microbiol Immunol, 48: 843-851.

Mace G, Feyeux C, Mollard N, Chantegret C, Audia S, Rebibou JM, Spagnolo G, Bour JB, Denoyel GA, Sagot P, Reynes JM. 2013. Severe Seoul hantavirus infection in a pregnant woman, France, October 2012. Euro Surveill, 18: 20464.

Maes P, Clement J, Gavrilovskaya I, Van Ranst M. 2004. Hantaviruses: immunology, treatment, and prevention. Viral Immunol, 17: 481-497.

Maes P, Clement J, Van Ranst M. 2009. Recent approaches in hantavirus vaccine development. Expert Rev Vaccines, 8: 67-76.

Manigold T, Vial P. 2014. Human hantavirus infections: epidemiology, clinical features, pathogenesis and immunology. Swiss Med Wkly, 144: w13937.

Martinez-Valdebenito C, Calvo M, Vial C, Mansilla R, Marco C, Palma RE, Vial PA, Valdivieso F, Mertz G, Ferres M. 2014. Person-to-person household and nosocomial transmission of andes hantavirus, Southern Chile, 2011. Emerg Infect Dis, 20: 1629-1636.

McElhinney L, Fooks AR, Featherstone C, Smith R, Morgan D. 2016. Hantavirus (Seoul virus) in pet rats: a zoonotic viral threat. Vet Rec, 178: 171-172.

Mustonen J, Makela S, Outinen T, Laine O, Jylhava J, Arstila PT, Hurme M, Vaheri A. 2013. The pathogenesis of nephropathia epidemica: new knowledge and unanswered questions. Antiviral Res, 100: 589-604.

Nelson R, Canate R, Pascale JM, Dragoo JW, Armien B, Armien AG, Koster F. 2010. Confirmation of Choclo virus as the cause of hantavirus cardiopulmonary syndrome and high serum antibody prevalence in Panama. J Med Virol, 82: 1586-1593.

Newman EN, Johnstone P, Bridge H, Wright D, Jameson L, Bosworth A, Hatch R, Hayward-Karlsson J, Osborne J, Bailey MS, Green A, Ross D, Brooks T, Hewson R. 2014. Seroconversion for infectious pathogens among UK military personnel deployed to Afghanistan, 2008-2011. Emerg Infect Dis, 20: 2015-2022.

Nikolic V, Stajkovic N, Stamenkovic G, Cekanac R, Marusic P, Siljic M, Gligic A, Stanojevic M. 2014. Evidence of recombination in Tula virus strains from Serbia. Infect Genet Evol, 21: 472-478.

Noh JY, Cheong HJ, Song JY, Kim WJ, Song KJ, Klein TA, Lee SH, Yanagihara R, Song JW. 2013. Clinical and molecular epidemiological features of hemorrhagic fever with renal syndrome in Korea over a 10-year period. J Clin Virol, 58: 11-17.

Onishchenko GG, Ezhlova EB. 2013. Epidemiologic surveillance and prophylaxis of hemorrhagic fever with renal syndrome in Russian Federation. Zh Mikrobiol Epidemiol Immunobiol: 23-32. (In Russian)

Padula P, Della Valle MG, Alai MG, Cortada P, Villagra M, Gianella A. 2002. Andes virus and first case report of Bermejo virus causing fatal pulmonary syndrome. Emerg Infect Dis, 8: 437 439.

Papa A. 2012. Dobrava-Belgrade virus: phylogeny, epidemiology, disease. Antiviral Res, 95: 104-117.

Papa A, Vaheri A, LeDuc JW, Kruger DH, Avsic-Zupanc T, Arikawa J, Song JW, Markotic A, Clement J, Liang M, Li D, Yashina LN, Jonsson CB, Schmaljohn CS. 2016. Meeting report: Tenth International Conference on Hantaviruses. Antiviral Res, 133: 234-241.

Pattamadilok S, Lee BH, Kumperasart S, Yoshimatsu K, Okumura M, Nakamura I, Araki K, Khoprasert Y, Dangsupa P, Panlar P, Jandrig B, Kruger DH, Klempa B, Jakel T, Schmidt J, Ulrich R, Kariwa H, Arikawa J. 2006. Geographical distribution of hantaviruses in Thailand and potential human health significance of Thailand virus. Am J Trop Med Hyg, 75: 994-1002.

Peters CJ, Khan AS. 2002. Hantavirus pulmonary syndrome: the new American hemorrhagic fever. Clin Infect Dis, 34: 12241231.

Pettersson L, Boman J, Juto P, Evander M, Ahlm C. 2008. Outbreak of Puumala virus infection, Sweden. Emerg Infect Dis, 14: 808-810.

Plyusnina A, Ferenczi E, Racz GR, Nemirov K, Lundkvist A, Vaheri A, Vapalahti O, Plyusnin A. 2009a. Co-circulation of three pathogenic hantaviruses: Puumala, Dobrava, and Saaremaa in Hungary. J Med Virol, 81: 2045-2052.

Plyusnina A, Ibrahim IN, Plyusnin A. 2009b. A newly recognized hantavirus in the Asian house rat (Rattus tanezumi) in Indonesia. J Gen Virol, 90: 205-209.

Rawlings JA, Torrez-Martinez N, Neill SU, Moore GM, Hicks BN, Pichuantes S, Nguyen A, Bharadwaj M, Hjelle B. 1996. Cocirculation of multiple hantaviruses in Texas, with characterization of the small $(\mathrm{S})$ genome of a previously undescribed virus of cotton rats (Sigmodon hispidus). Am J Trop Med Hyg, 55: $672-679$.

Rhodes LV, 3rd, Huang C, Sanchez AJ, Nichol ST, Zaki SR, Ksiazek TG, Humphreys JG, Freeman JJ, Knecht KR. 2000. Hantavirus pulmonary syndrome associated with Monongahela virus, Pennsylvania. Emerg Infect Dis, 6: 616-621.

Rollin PE, Nawrocka E, Rodhain F, Sureau P, McCormick JB. 1986. Serological data on hemorrhagic fever with renal syndrome in Southeast Asia. Bull Soc Pathol Exot Filiales, 79: 473-475. (In French)

Rovida F, Percivalle E, Sarasini A, Chichino G, Baldanti F. 2013. Imported hantavirus cardiopulmonary syndrome in an Italian traveller returning from Cuba. New Microbiol, 36: 103-105.

Sandmann S, Meisel H, Razanskiene A, Wolbert A, Pohl B, Kruger DH, Sasnauskas K, Ulrich R. 2005. Detection of human hantavirus infections in Lithuania. Infection, 33: 66-72.

Schmaljohn C, Hjelle B. 1997. Hantaviruses: a global disease problem. Emerg Infect Dis, 3: 95-104. 
Song G. 1999. Epidemiological progresses of hemorrhagic fever with renal syndrome in China. Chin Med J (Engl), 112: 472477.

Spengler JR, Haddock E, Gardner D, Hjelle B, Feldmann H, Prescott J. 2013. Experimental Andes virus infection in deer mice: characteristics of infection and clearance in a heterologous rodent host. PLoS One, 8: e55310.

Spiropoulou CF, Albarino CG, Ksiazek TG, Rollin PE. 2007. Andes and Prospect Hill hantaviruses differ in early induction of interferon although both can downregulate interferon signaling. J Virol, 81: 2769-2776.

Suharti C, van Gorp EC, Dolmans WM, Groen J, Hadisaputro S, Djokomoeljanto RJ, D MEO, van der Meer JW. 2009. Hanta virus infection during dengue virus infection outbreak in Indonesia. Acta Med Indones, 41: 75-80.

Sunil-Chandra NP, Clement J, Maes P, HJ DES, M VANE, M VANR. 2015. Concomitant leptospirosis-hantavirus co-infection in acute patients hospitalized in Sri Lanka: implications for a potentially worldwide underestimated problem - ERRATUM. Epidemiol Infect, 143: 2094.

Suputthamongkol Y, Nitatpattana N, Chayakulkeeree M, Palabodeewat S, Yoksan S, Gonzalez JP. 2005. Hantavirus infection in Thailand: first clinical case report. Southeast Asian J Trop Med Public Health, 36: 700-703.

Tervo L, Makela S, Syrjanen J, Huttunen R, Rimpela A, Huhtala H, Vapalahti O, Vaheri A, Mustonen J. 2015. Smoking is associated with aggravated kidney injury in Puumala hantavirus-induced haemorrhagic fever with renal syndrome. Nephrol Dial Transplant, 30: 1693-1698.

Torres-Perez F, Boric-Bargetto D, Palma Vasquez RE. 2016. Hantavirus in Chile: New rodents with potential epidemiological importance. Rev Med Chil, 144: 818. (In Spanish)

Truong TT, Yoshimatsu K, Araki K, Lee BH, Nakamura I, Endo R, Shimizu K, Yasuda SP, Koma T, Taruishi M, Okumura M, Truong UN, Arikawa J. 2009. Molecular epidemiological and serological studies of hantavirus infection in northern Vietnam. J Vet Med Sci, 71: 1357-1363.

Vaheri A, Strandin T, Hepojoki J, Sironen T, Henttonen H, Makela S, Mustonen J. 2013. Uncovering the mysteries of hantavirus infections. Nat Rev Microbiol, 11: 539-550.

Van Cuong N, Carrique-Mas J, Vo Be H, An NN, Tue NT, Anh NL, Anh PH, Phuc NT, Baker S, Voutilainen L, Jaaskelainen A, Huhtamo E, Utriainen M, Sironen T, Vaheri A, Henttonen H, Vapalahti O, Chaval Y, Morand S, Bryant JE. 2015. Rodents and risk in the Mekong Delta of Vietnam: seroprevalence of selected zoonotic viruses in rodents and humans. Vector Borne Zoonotic Dis, 15: 65-72.

Vitarana T, Colombage G, Bandaranayake V, Lee HW. 1988. Hantavirus disease in Sri Lanka. Lancet, 2: 1263.

Vollmar P, Lubnow M, Simon M, Muller T, Bergler T, Alois P, Thoma BR, Essbauer S. 2016. Hantavirus cardiopulmonary syndrome due to Puumala virus in Germany. J Clin Virol, 84: 42-47.

Wang J, Guo W, Du H, Yu H, Jiang W, Zhu T, Bai X, Wang P. 2014. Elevated soluble CD163 plasma levels are associated with disease severity in patients with hemorrhagic fever with renal syndrome. PLoS One, 9: e112127.

Wang W, Zhang Y, Li Y, Pan L, Bai L, Zhuang Y, Huang CX, Wang JP, Yu HT, Wei X, Jiang W, Nan YY, Yang DQ, Su WJ, Wang PZ, Bai XF. 2012. Dysregulation of the beta3 integrinVEGFR2 complex in Hantaan virus-directed hyperpermeability upon treatment with VEGF. Arch Virol, 157: 1051-1061.

Weiss S, Witkowski PT, Auste B, Nowak K, Weber N, Fahr J, Mombouli JV, Wolfe ND, Drexler JF, Drosten C, Klempa B,
Leendertz FH, Kruger DH. 2012. Hantavirus in bat, Sierra Leone. Emerg Infect Dis, 18: 159-161.

Witkowski PT, Klempa B, Ithete NL, Auste B, Mfune JK, Hoveka J, Matthee S, Preiser W, Kruger DH. 2014. Hantaviruses in Africa. Virus Res, 187: 34-42.

Witkowski PT, Leendertz SA, Auste B, Akoua-Koffi C, Schubert G, Klempa B, Muyembe-Tamfum JJ, Karhemere S, Leendertz FH, Kruger DH. 2015. Human seroprevalence indicating hantavirus infections in tropical rainforests of Cote d'Ivoire and Democratic Republic of Congo. Front Microbiol, 6: 518.

Wong TW, Chan YC, Lee HW. 1985. Haemorrhagic fever with renal syndrome in Singapore: a case report. Southeast Asian J Trop Med Public Health, 16: 525-527.

Yao L, Kang Z, Liu Y, Song F, Zhang X, Cao X, Zhang Y, Yang Y, Sun X, Wang J, Hu K, Liu L, Chen W, Shao L, Xu B, Wang B. 2013. Seoul virus in rats (Rattus norvegicus), Hyesan, North Korea, 2009-2011. Emerg Infect Dis, 19: 1895-1896.

Yao LS, Qin CF, Pu Y, Zhang XL, Liu YX, Liu Y, Cao XM, Deng YQ, Wang J, Hu KX, Xu BL. 2012. Complete genome sequence of Seoul virus isolated from Rattus norvegicus in the Democratic People's Republic of Korea. J Virol, 86: 13853.

Yu H, Jiang W, Du H, Xing Y, Bai G, Zhang Y, Li Y, Jiang H, Zhang Y, Wang J, Wang P, Bai X. 2014. Involvement of the Akt/NF-kappaB pathways in the HTNV-mediated increase of IL-6, CCL5, ICAM-1, and VCAM-1 in HUVECs. PLoS One, 9: e93810.

Yu HT, Jiang H, Zhang Y, Nan XP, Li Y, Wang W, Jiang W, Yang DQ, Su WJ, Wang JP, Wang PZ, Bai XF. 2012. Hantaan virus triggers TLR4-dependent innate immune responses. Viral Immunol, 25: 387-393.

$\mathrm{Yu}$ XJ, Tesh RB. 2014. The role of mites in the transmission and maintenance of Hantaan virus (Hantavirus: Bunyaviridae). J Infect Dis, 210: 1693-1699.

Zelena H, Mrazek J, Kuhn T. 2013. Tula hantavirus infection in immunocompromised host, Czech Republic. Emerg Infect Dis, 19: $1873-1875$.

Zhang S, Wang S, Yin W, Liang M, Li J, Zhang Q, Feng Z, Li D. 2014. Epidemic characteristics of hemorrhagic fever with renal syndrome in China, 2006-2012. BMC Infect Dis, 14: 384.

Zhang WY, Wang LY, Liu YX, Yin WW, Hu WB, Magalhaes RJ, Ding F, Sun HL, Zhou H, Li SL, Haque U, Tong SL, Glass GE, Bi P, Clements AC, Liu QY, Li CY. 2014. Spatiotemporal transmission dynamics of hemorrhagic fever with renal syndrome in China, 2005-2012. PLoS Negl Trop Dis, 8: e3344.

Zhang Y, Liu BH, Lin F, Zhang YG, Si BY, Kang XP, Hu Y, Li J, Wu XY, Li YC, Zhu QY, Yang YH. 2013. The first complete genomic characterization of an Amur virus isolate from China. Arch Virol, 158: 2185-2188.

Zhang YZ. 2014. Discovery of hantaviruses in bats and insectivores and the evolution of the genus Hantavirus. Virus Res, 187: $15-21$.

Zou LX, Chen MJ, Sun L. 2016. Haemorrhagic fever with renal syndrome: literature review and distribution analysis in China. Int J Infect Dis, 43: 95-100.

Zuo SQ, Fang LQ, Zhan L, Zhang PH, Jiang JF, Wang LP, Ma JQ, Wang BC, Wang RM, Wu XM, Yang H, Cao ZW, Cao WC. 2011. Geo-spatial hotspots of hemorrhagic fever with renal syndrome and genetic characterization of Seoul variants in Beijing, China. PLoS Negl Trop Dis, 5: e945.

Zuo SQ, Gong ZD, Fang LQ, Jiang JF, Zhang JS, Zhao QM, Cao WC. 2014. A new hantavirus from the stripe-backed shrew (Sorex cylindricauda) in the People's Republic of China. Virus Res, 184: 82-86. 